\title{
THE USE OF MUSSEL SHELL AS A BIO-ADDITIVE FOR POLY(LACTIC ACID) BASED GREEN COMPOSITES
}

\author{
Metehan Oğulcan Lap ${ }^{1}$, Yasin Kanbur ${ }^{2}, \ddot{U} m i t$ Tayfun $^{1,3, 凶}$
}

https://doi.org/10.23939/chcht15.04.621

\begin{abstract}
Mussel shell is one of the most hazardous aquaculture wastes and its powder was used as an additive for bio-degradable poly (lactic acid) in this current study. Bio-composites were fabricated via conventional melt mixing technique followed by an injection moulding process. The effects of mussel shell powder inclusion on mechanical, melt-flow, water uptake and morphological performance of poly (lactic acid)-based green composites were reported.
\end{abstract}

Keywords: green composites, poly(lactic acid), mussel shell, bio-filler, polymer composites.

\section{Introduction}

Polymer matrix composites are the most favorable type among composite materials since they are suitable for practical fabrication. Thermoplastic polymers have so many advantages over thermosets including the easiness of processing and recyclability using conventional production techniques [1-3]. Additives are generally referred fillers and they are incorporated to polymers for the contributions of cost-reduction, property improvement or regulation of processing [4-6].

Eco-friendly composites have been gathering much more attention since environmental concerns and regulations are increasing in recent years. Green composites have several advantages including bio-degradability, recyclability, low weight and cost-effectiveness [7-10]. These properties open ways to green composites for potential replacement with non-degradable polymers based on petroleum in several application fields from packaging to transportation $[11,12]$. Among these application areas, automotive industry is the biggest market and is expected to retain its leadership for a long time according to the latest report [13]. There is an increasing trend for the use of natural fibers filled polymer composites in production of

\footnotetext{
${ }^{1}$ Chemistry Dept., Izmir Institute of Technology, Izmir, Turkey

${ }^{2}$ Chemistry Dept., Karabuk University, Karabuk, Turkey

${ }^{3}$ Inovasens Ltd.,Izmir Technopark, Izmir, Turkey

凶umit.tayfun@inovasens.com

(c) Lap M., Kanbur Y., Tayfun Ü., 2021
}

automotive parts mainly in door panels, seat backs, trunk liners and package trays $[14,15]$. Fabrication of composites using polymers derived from natural resources such as poly(lactic acid) (PLA) with agricultural wastes makes the material more environmentally friendly.

PLA is the most popular member of commercial eco-grade polymers. Biodegradable feature of PLA makes its usage in various products safe for the environment. It has numerous advantageous points over other biodegradable polymers including the high mechanical strength, bio-compatibility and practical processing with conventional techniques [16]. On the other hand, PLA has some limitations which restrict its broad range usage. Some examples of these disadvantages are having hydrophobic nature, poor toughness, low degradation rate and chemical inertness due to the absence of reactive side chain groups in its structure [17]. Research efforts toward the enhancements of its performance such as thermal, structural, mechanical and water resistance have been conducted by material scientists to remove the limitations on applications of PLA [18-21].

Aquacultural waste products are considered as one of the environmental hazards due to toxic odour and microbial diseases. Seashell wastes such as mussel shell (MS) are among these crops which are the disposal of shellfish farming of oyster and food industry $[22,23]$. The difficulty of landfilling of seashells leads to attentions based on the recycling or re-use of these undesired by-products. For this reason, the potential use of seashell residues in various industrial applications are investigated mainly by Japanese and Korean researchers thanks to the efficient investments facilitated by their governments. Consequently, seashell crops were converted into promising products for several application fields such as fertilizer, waste-water absorber, liming material and additives for concrete, plastic, eco-grade paint and coatings [24-27].

Mussel shell is one of shell waste products. According to literature survey, it has been used as an additive for several polymers including polyethylene [28], polypropylene [29-32] and epoxy resin [33]. MS filled PLA composite system has not been found in the literature. Since the structure of MS consists of calcium carbonate (CC) with nearly $96 \%$ composition [34, 35], 
PLA/MS can be considered as PLA/CC composites. There has been postulated some research works related with PLA containing $\mathrm{CC}$ in which their bio-medical applications were mainly studied [36-39].

In this current study, MS waste was obtained from local sources and converted to powder form by a grinding process. MS containing PLA based bio-composites were developed via melt blending using a lab-scale microcompounder. Filler loadings were in the range of 10$40 \mathrm{wt} \%$. Test samples were prepared by the injection moulding process. The effect of MS additions on mechanical, melt-flow, water uptake and morphological properties of PLA based eco-composites were investigated by tensile, shore hardness and impact tests, melt flow index (MFI) test, water absorption test and scanning electron microscopy (SEM) technique, respectively.

\section{Experimental}

\subsection{Materials}

The commercial PLA was purchased from Natureworks LLC, USA under the trade name of Ingeo Biopolymer 6100D. This fiber grade PLA has a density and relative viscosity of $1.24 \mathrm{~g} / \mathrm{cm}^{3}$ (ASTM D792) and 3.1 (CD Internal viscotek method) as provided by the supplier, respectively. Mussel shells were obtained from the local sources in Karaburun, Izmir. They were cleaned and ground to a powder form using a lab-scale grind mill. Particle size of MS powder was nearly 200 microns.

\subsection{Preparation of Composites}

PLA/MS bio-composites were fabricated using a lab-scale twin screw extruder (15 ml Micro-compounder, DSM Xplore, Netherlands). Loading ratios of MS were varied from 10, 20, 30 and $40 \mathrm{wt} \%$. The samples obtained from an extrusion process were cut into a chip form and shaped by a lab-scale injection moulding instrument (Micro-injector, Daca Instruments, UK). Processing parameters applied at extrusion and injection moulding stages are listed in Table 1.

\section{Table 1}

\section{Processing conditions of PLA and PLA/MS composites}

\begin{tabular}{|c|c|c|}
\hline Parameters & Value & Unit \\
\hline Process temperature & 473 & $\mathrm{~K}$ \\
\hline Mixing time & 5 & $\mathrm{~min}$ \\
\hline Screw speed & 100 & $\mathrm{rpm}$ \\
\hline Barrel temperature & 478 & $\mathrm{~K}$ \\
\hline Mould temperature & 333 & $\mathrm{~K}$ \\
\hline Injection pressure & 800 & $\mathrm{kPa}$ \\
\hline Holding time & 3 & $\mathrm{~min}$ \\
\hline
\end{tabular}

\subsection{Characterization Methods}

Tensile test measurements of PLA and its composites were carried out in accordance with the ASTM D-638 standard using Lloyd LR $30 \mathrm{~K}$ universal tensile testing machine. $5 \mathrm{kN}$ load cell and $5 \mathrm{~cm} / \mathrm{min}$ crosshead speed were used during the test. Tensile strength, percentage elongation at break and tensile modulus parameters were recorded as an average of five samples.

Zwick R5LB041 digital Shore hardness tester was used according to ISO 7619-1 standard in order to investigate the effect of MS additions to the hardness of PLA composites.

Impact energy values were measured via CoesfeldMaterial impact tester using 4J pendulum. Charpy unnotched samples subjected to impact tests and impact energy values were determined as an average of at least five samples.

MFI values of PLA and composites were investigated using Coesfield Meltfixer LT. Test measurements were carried out under the specified load of $2.16 \mathrm{~kg}$ at the process temperature of PLA ( $473 \mathrm{~K}$ ).

In order to determine the water absorption properties of composites, test specimens with dimensions of $7.4 \times 2.0 \times 80 \mathrm{~mm}^{3}$ were conditioned according to ASTM D570 procedure. They were immersed in a water bath at room temperature, periodically taken out from the water, wiped with a tissue paper to remove their surface water, reweighed and immediately put back into water repeatedly.

Morphological characterizations of composites were examined by the field emission scanning electron microscope (JSM-6400 Electron Microscope). Surfaces of fractured samples obtained from the impact test were coated with a thin layer of gold in order to obtain conductive surface. SEM micrographs were taken at $\times 500, \times 1000$ and $\times 2000$ magnifications.

\section{Results and Discussion}

\subsection{Tensile Test}

Tensile test data provides a basic mechanical behaviour of the material. According to tensile strength results represented in Fig. 1, the inclusion of MS to PLA matrix caused slight improvements for ta ensile strength parameter. The remarkable improvement in the tensile strength was observed up to $20 \%$ loading level of MS, with the addition of mussel shell powder to the PLA matrix. Further additions of MS yield a slight reduction in the tensile strength of composites. This may be due to the formation of aggregation of MS particles after $20 \%$ 
concentration which results in a significant decrease of dispersion homogeneity for MS into the polymer matrix $[40,41]$. For this reason, PLA/20 MS composite exhibited the highest tensile strength among samples.

Percent elongation of PLA and PLA/MS composites is given in Fig. 2. Elongation of unfilled PLA displayed the reduction trend by the addition of MS regardless of concentration. Accordingly, the highest percent elongation value was obtained for the lowest

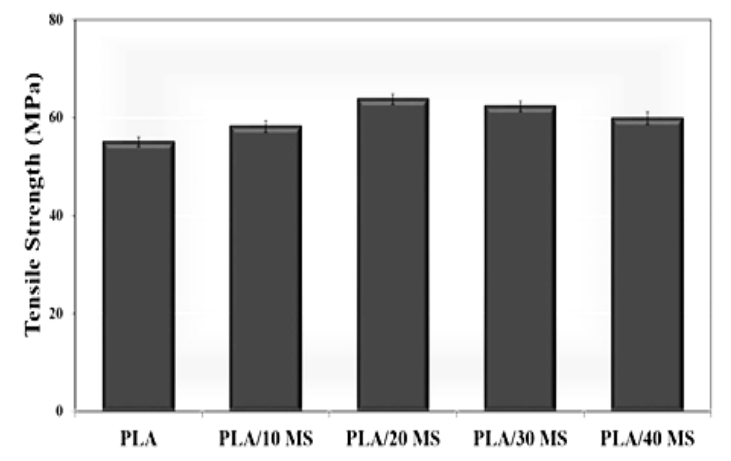

Fig. 1. Tensile strength values of PLA and composites

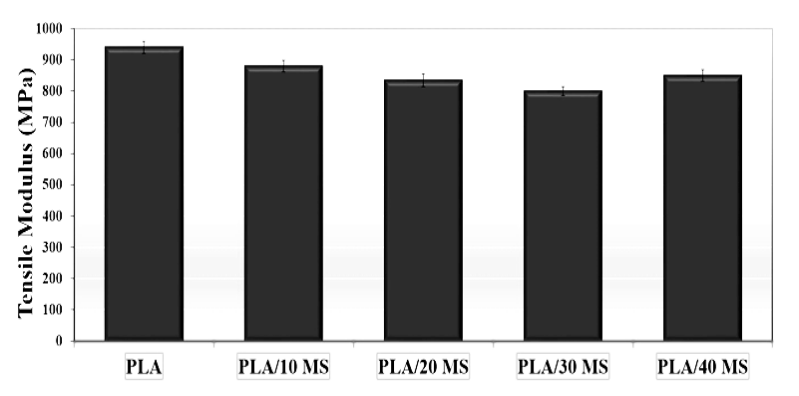

Fig. 3. Modulus values of PLA and composites

\subsection{Impact Test}

According to impact test results displayed in Fig. 4, MS filled composites showed the higher impact energy with respect to unfilled PLA. Impact strength values of all of the composites were found to be higher than PLA. The highest impact energy was achieved for $20 \%$ MS loaded composite. Toughness of unfilled PLA was improved by the addition of MS powder regardless of the concentration which was attributed to gain ability to absorb more energy during the impact deformation after the filler loading [45, 46].

\subsection{Hardness Tests}

Shore hardness is a characteristic parameter of polymeric materials in terms of their potential applications. concentration of MS among composite samples. Particulate filler additions yield the decrease in elongation of thermoplastics since the incorporated filler particles restricted the motion of the polymer chains [42-44].

According to tensile modulus results of PLA and relevant composites displayed in Fig. 3, the incorporation of MS caused the decrease in a tensile modulus of PLA. The lowest modulus value was observed for $30 \%$ MS containing the composite according to Fig. 3.

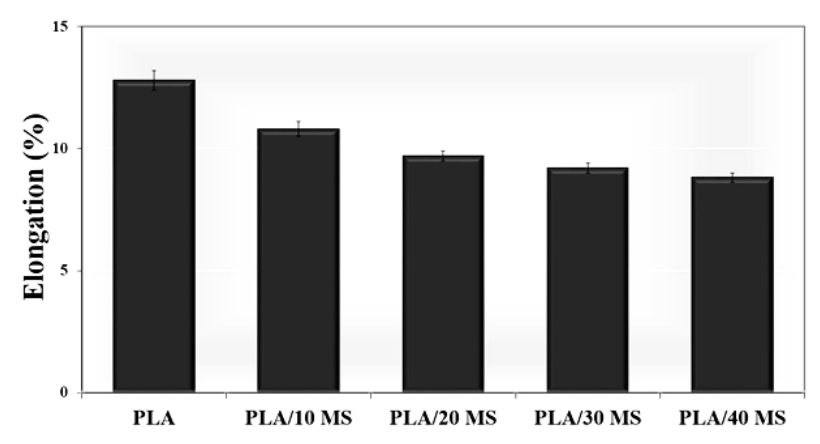

Fig. 2. Elongation values of PLA and composites

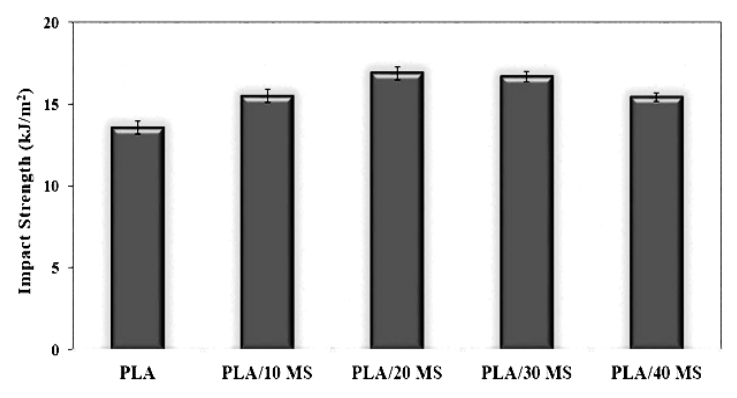

Fig. 4. Impact test results of PLA and composites

Shore A and Shore D hardness values of unfilled PLA and its composites were listed in Table 2.

Table 2

Shore hardness values of PLA and composites

\begin{tabular}{|c|c|c|}
\hline Samples & Shore A & Shore D \\
\hline PLA & 95.0 & 50.3 \\
\hline PLA/10 MS & 96.3 & 53.8 \\
\hline PLA/20 MS & 97.1 & 56.4 \\
\hline PLA/30 MS & 98.8 & 58.9 \\
\hline PLA/40 MS & 98.4 & 58.7 \\
\hline
\end{tabular}

MS inclusions shifted the hardness of PLA to higher values. According to the Shore A hardness test, the hardness value of MS filled composites raised steadily with the increase in the concentration of MS. Accordingly, 
Shore D type hardness values exhibited an increasing trend by the addition of MS. The highest hardness results were obtained for a filling ratio of $30 \% \mathrm{MS}$ in the composite. These results are in agreement with similar works in which the improvement in hardness values of polymers was observed after CC loadings [47].

\subsection{Melt Flow Measurements}

MFI measurements provide characteristic processing parameters of the polymeric materials in large-scale applications in case of the melt blending process is preferred. MFI values of PLA and relevant composites are displayed in Fig. 5. Significant increase in MFI values was observed with the addition of MS into PLA matrix. This may be attributed to the increasing density of composites after the incorporation of MS [48, 49]. MFI value of unfilled PLA showed no obvious change with the addition of MS which indicates that processing of composites can be performed practically in industrial applications.

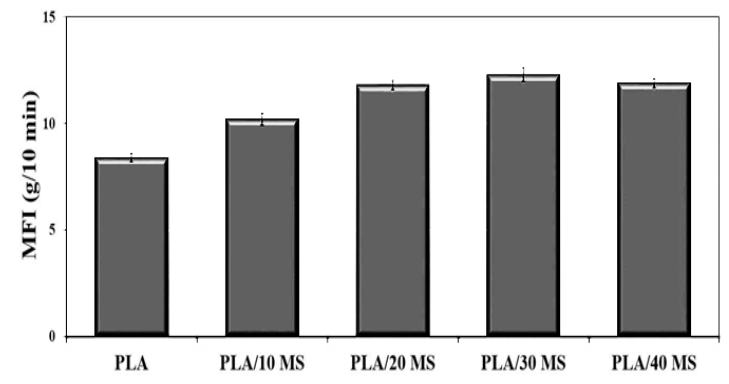

Fig. 5. MFI test results of PLA and composites

\subsection{Water Uptake Study}

Water uptake results of PLA and PLA/MS composites in 30 days' period of time are listed in Table 3. Water absorption of pristine PLA reached $0.9 \%$ for a few days and then this value remained constant throughout the test. In contrast, MS containing composites gave higher water absorption values at the end of the test interval. The hydrophilic nature of CC in MS structure caused the penetration of water into PLA matrix and higher water uptake values were found after MS additions.

Table 3

Water absorption test results of PLA and composites

\begin{tabular}{|c|c|}
\hline Samples & Water uptake in 30 days, $\%$ \\
\hline PLA & 0.9 \\
\hline PLA/10 MS & 1.6 \\
\hline PLA/20 MS & 2.4 \\
\hline PLA/30 MS & 3.1 \\
\hline PLA/40 MS & 3.8 \\
\hline
\end{tabular}

\subsection{SEM Observations}

SEM micrographs provided the optical confirmation of comparability of MS and PLA phases. As the SEM micrographs of the composites are examined from Fig. 6, it is seen that poor adhesion between PLA phase and filler interface were observed for the composites with higher concentrations of MS (30\% and $40 \%$ ) and large gaps between two phases were investigated. On the other hand, MS containing composites with lower loading levels $(10 \%$ and $20 \%)$ displayed more homogeneous dispersion and better adhesion compared to higher filling ratios of MS. In other words, particle-matrix adhesion was achieved for small amounts of MS up to $20 \%$ concentration. Further additions of MS yield particleparticle interactions and MS particles tend to form agglomerates instead of dispersion into PLA matrix. These outcomes confirmed the previous findings which implied that $20 \%$ filling ratio of MS gave the highest mechanical performance among prepared composites.
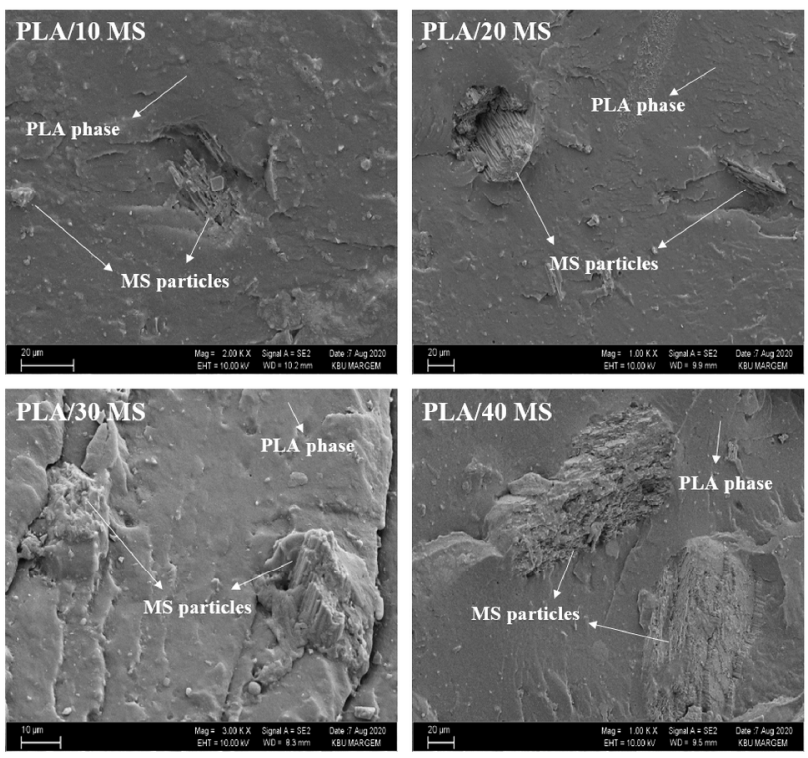

Fig. 6. SEM micrographs of composites

\section{Conclusions}

Tensile test results show that the inclusion of MS improves the tensile strength of unfilled PLA. The highest strength values were achieved by $20 \%$ MS loaded composite sample. MS additions caused the decrease in tensile modulus of unfilled PLA. Relatively lower percent elongation values were found for composites compared to PLA. According to Shore A and Shore D test results, MS inclusions to PLA matrix led to the significant increase in hardness values of PLA. Water uptake of PLA extended to higher values by the addition of MS since the mussel 
shell contains mostly calcium carbonate in its structure. MFI values were found in a narrow range. This means that MS addition caused no obvious problems in the case of processing stages of composites considered in scale-up studies. Dispersion of MS powder was examined by SEM photographs and it was found that formations of agglomeration increase for the higher loading levels of MS. Composites containing MS at lower concentrations exhibited relatively more homogeneous dispersion with respect to higher loading levels of MS. The optimum concentration of MS filled PLA composites was estimated as $20 \mathrm{wt} \%$ according to findings.

\section{Acknowledgements}

This research work was represented at International Scientific and Technical Conference on Modern Technologies of Receiving and Processing of Polymeric Materials (TPM-2019) which was held on November 6-8, 2019 at Lviv Polytechnic National University. The presentation was selected as the $3^{\text {rd }}$ degree oral report award by the organizing committee of the conference.

\section{References}

[1] Mazumdar S.: Composites Manufacturing Materials, Product, and Process Engineering. CRC Press LLC, Boca Raton 2002. [2] Akovali G.: Handbook of Composite Fabrication. Rapra Technology, Shawbury 2001.

[3] Sabu T., Kuruvilla J., Malhotra S. et al.: Polymer Composites. Wiley VCH 2012.

[4] Katz H., Milewsky J.: Handbook of Fillers for Plastics, Van Nostrand Reinhold 1987.

[5] Gächter R., Müller H.: Plastics Additives. Hanser Verlag 1990.

[6] Xanthos M.: Functional Fillers for Plastics. Wiley VCH 2005.

[7] Mohanty A., Misra M., Drzal L.: J. Polym. Environ., 2002, 10, 19. https://doi.org/10.1023/A:1021013921916

[8] Emadian M., Onay T., Demirel B.: Waste Manag., 2017, 59,

526. https://doi.org/10.1016/j.wasman.2016.10.006

[9] Bajpai P., Ahmad F., Chaudhary V.: Processing and

Characterization of Bio-Composites [in:] Martínez L., Kharissova O., Kharisov B. (Eds.), Handbook of Ecomaterials. Springer 2017. https://doi.org/10.1007/978-3-319-48281-1_98-1

[10] Falinski M., Plata D., Chopra S. et al.: Nature Nanotech., 2018, 13, 708. https://doi.org/10.1038/s41565-018-0120-4

[11] Dicker M., Duckworth P., Baker A. et al.: Compos. Part AAppl. S., 2014, 56, 280.

https://doi.org/10.1016/j.compositesa.2013.10.014

[12] Saba N., Jawaid M., Sultan M., et al.: Green Biocomposites for Structural Applications [in:] Jawaid M., Salit M., Alothman O. (Eds.), Green Biocomposites. Green Energy and Technology. Springer 2017. https://doi.org/10.1007/978-3-319-49382-4_1 [13] Faruk O., Bledzki A., Fink H. et al.: Macromol. Mater. Eng., 2014, 299, 9. https://doi.org/10.1002/mame.201300008

[14] Koronis G., Silva A., Fontul M.: Compos. Part B-Eng., 2013, 44, 120. https://doi.org/10.1016/j.compositesb.2012.07.004
[15] Akampumuza O., Wambua P., Ahmed A., et al.: Polym. Compos., 2017, 38, 2553. https://doi.org/10.1002/pc.23847

[16] Ghanbarzadeh B., Almasi H.: Biodegradable Polymers. Intech 2013.

[17] Rasal R., Janorkar A., Hirt D.: Prog. Polym. Sci., 2010, 35,

338. https://doi.org/10.1016/j.progpolymsci.2009.12.003

[18] Siakeng R., Jawaid M., Ariffin H. et al.: Polym. Compos.,

2019, 40, 446. https://doi.org/10.1002/pc.24747

[19] Ren J.: Biodegradable Poly(lactic acid): Synthesis,

Modification, Processing and Applications, Springer-Verlag 2011.

[20] Tayfun U., Dogan M.: Polym. Bull., 2016, 73, 1581.

https://doi.org/10.1007/s00289-015-1564-4

[21] Bajpai P., Singh I., Madaan J.: J. Thermoplast. Compos.

Mater., 2012, 27, 52. https://doi.org/10.1177/0892705712439571

[22] Mo K., Alengaram U., Jumaat M. el al.: Construct. Build.

Mater., 2018, 162, 751.

https://doi.org/10.1016/j.conbuildmat.2017.12.009

[23] Yao Z., Xia M., Li H. et al.: Crit. Rev. Environ. Sci.Technol.,

2014, 44, 2502. https://doi.org/10.1080/10643389.2013.829763

[24] Yoon G.-L., Kim B.-T., Kim B.-O. et al.: Waste Manag., 2003,

23, 825. https://doi.org/10.1016/S0956-053X(02)00159-9

[25] Funabashi M., Ninomiya F., Flores E. et al.: J. Polym.

Environ., 2010, 18, 85. https://doi.org/10.1007/s10924-010-0166-3

[26] Lee C., Lee D., Ali M. et al.: Waste Manag., 2008, 28, 2702.

https://doi.org/10.1016/j.wasman.2007.12.005

[27] Yang E., Kim M., Park H. et al.: Construct. Build. Mater.,

2010, 24, 758. https://doi.org/10.1016/j.conbuildmat.2009.10.032

[28] Chong M., Chun B., Chung Y. et al.: J. Appl. Polym. Sci.,

2006, 99, 1583. https://doi.org/10.1002/app.22484

[29] Yao Z., Xia M., Ge L. et al.: Fibers Polym. 2014, 5, 1278.

https://doi.org/10.1007/s12221-014-1278-5

[30] Li H., Tan Y., Zhang L., et al.: J. Inorg. Mater., 2012, 27, 977. https://doi.org/10.3724/SP.J.1077.2012.11653

[31] Xia M., Yao Z., Ge L. et al.: J. Compos. Mater., 2015, 49, 807. https://doi.org/10.1177/0021998314525981

[32] Li H., Tan Y., Zhang L. et al.: J. Hazard. Mater., 2012, 217,

256. https://doi.org/10.1016/j.jhazmat.2012.03.028

[33] Kocaman S., Ahmetli G., Cerit A., et al.: Int. J. Metall. Mater. Eng., 2016, 10, 438. https://doi.org/10.5281/zenodo.1123921

[34] Marin F., Le R., Marie B.: Front. Biosci., 2012, 4, 125.

https://doi.org/10.2741/321

[35] Hamester M., Balzer P., Becker D.: Mater. Res., 2012, 15, 204. https://doi.org/10.1590/S1516-14392012005000014

[36] Kalia S., Avérous L.: Biodegradable and Biobased Polymers for Environmental and Biomedical Applications. John Wiley \& Sons 2016.

[37] Yang Y., Zhang L., Xiong Z. et al.: Sci. China Chem., 2016,

59, 1355. https://doi.org/10.1007/s1 1426-016-0222-7

[38] Kasuga T., Maeda H., Kato K. et al.: Biomater., 2003, 24,

3247. https://doi.org/10.1016/S0142-9612(03)00190-X

[39] Flahiff C., Blackwell A., Hollis J. et al.: J. Biomed. Mater.

Res., 1998, 32, 419. https://doi.org/10.1002/(SICI) 1097-

4636(199611)32:3<419::AID-JBM15>3.0.CO;2-B

[40] Kanbur Y., Tayfun U.: J. Elastom. Plast., 2019, 51, 262.

https://doi.org/10.1177/0095244318796616

[41] Lee J., Hong J., Ahn K.: Polym. Compos., 2019, 40, 4023.

https://doi.org/10.1002/pc.25263

[42] Alghadi A., Tirkes S., Tayfun U.: Mater. Res. Express, 2020, 7, 015301. https://doi.org/10.1088/2053-1591/ab551b

[43] Fu S., Feng X., Lauke B. et al.: Compos. Part B-Eng., 2008, 39,

933. https://doi.org/10.1016/j.compositesb.2008.01.002 
[44] Dike A., Tayfun U., Dogan M.: Fire Mater., 2017, 41, 890. https://doi.org/10.1002/fam.2428

[45] Avolio R., Castaldo R., Avella M. et al.: Compos. Part B-Eng., 2018, 152, 267. https://doi.org/10.1016/j.compositesb.2018.07.011 [46] Eselini N., Tirkes S., Akar A., et al.: J. Elastom. Plast., 2020, 52, 701. https://doi.org/10.1177/0095244319884716

[47] Bratychak M., Astakhova O., Shyshchak O. et al.: Chem. Chem. Technol., 2019, 13, 360.

https://doi.org/10.23939/chcht13.03.360

[48] Tayfun U., Dogan M., Bayramli E.: Polym. Compos., 2017, 38, 2874. https://doi.org/10.1002/pc.23889

[49] Kilinc K., Kanbur Y., Tayfun U.: Holzforschung, 2019, 73, 401. https://doi.org/10.1515/hf-2018-0116

Received: December 05, 2019 / Revised: January 12, 2020 / Accepted: March 13, 2020

\section{ВИКОРИСТАННЯ МІДІЕВИХ МУШЛЕЙ ЯК БІО- ДОБАВКИ ДЛЯ ЗЕЛЕНИХ КОМПОЗИТІВ НА ОСНОВІ ПОЛІ(МОЛОЧНОЇ КИСЛОТИ)}

Анотація. Як добавка до біодеградабельної полі(молочної кислоти) вивчено порошок мушлей мідій, які є одним $з$ найнебезпечніших відходів аквакультури. Біокомпозити виготовляли за допомогою звичайної техніки змімування розплаву з подальшим прочесом лиття під тиском. Визначено вплив порошку мушлі мідії на механічні властивості, властивості потоку розплаву, поглинання води та морфологічні показники зелених композитів на основі полі(молочної кислоти).

Ключові слова: зелені композити, полі(молочна кислота), оболонка мідії, біо-наповнювач, полімерні композити. 